\title{
SUCCESSFUL TRANSFER OF CROATIAN FAMILY BUSINESSES AS A PART OF THE EUROPEAN UNION POLICY - WHAT CAN WE DO?*
}

\author{
Mihaela Braut Filipović, PhD, Assistant Professor \\ University of Rijeka, Faculty of law \\ Department of commercial and company law \\ Hahlić 6, 51000 Rijeka, Croatia \\ mbraut@pravri.hr
}

\begin{abstract}
It is a well-known fact that family businesses are one of the most important pillars of European Union countries, which includes Croatia as well. However, family businesses more often fail then survive the transfer of business between the generations. Number of Croatian family businesses which are facing this challenge is rapidly growing due to the fact that Croatian companies were mostly established in 1990's, and the first owners are soon to be retired. The loss of any successful company is an inexcusable loss for the economy and social welfare. Thus, it is an old challenge how to help these companies in transition, whether through transfer between generations of the family or by selling the business. This issue has been acknowledged on the EU level, and there were several studies on the importance and challenges which family business face throughout the EU countries. Also, the EU institutions discussed the possible policies for enhancing the success of family business in transfer, example of which is a Resolution of the European Parliament on family businesses in Europe in 2015. Further, successful transfer of family business is one of the goals in European Commission Entrepreneurship 2020 Action Plan. In this paper, we shall discuss the proposed policies towards family businesses on the EU level, and whether these policies are employed in Croatia. The analysis shall include the EU programs for financing the transition of family business including the option for financing the third person in buying the successful family business. Authors shall assess whether EU policies adequately address the importance of special governance within these companies. This paper aims to further explore some possibilities for enhancing governance of family businesses which may attribute towards successful transfer of these companies. Also, author shall explore alternative solutions for transfer such as transfer of shares on family foundations which in turn continue managing the family company, but also financially support the family members. It is of particular interest to analyze whether EU policies support introducing new measures on na-
\end{abstract}

This paper is written under support of the University of Rijeka project (uniri-drustv-18-43) "Legal Aspects of Companies Restructuring and Transition Towards New Corporate Governance Culture" 
tional level which could provide for greater variety of options for entrepreneurs which face the challenge of ensuring the transfer of their business. The conclusion shall be drawn on whether policy for enhancing transfer of family businesses in Croatia is adequate, together with possible options which could be introduced in order to achieve that goal.

Keywords: family business in the EU, Croatian family business, business transfer, family governance

\section{INTRODUCTION}

Family businesses as a type of entrepreneurships in EU should be studied in order to understand different functions they provide for the economy and for the society. ${ }^{1}$ Also, the goal of these studies should be to increase efficiency of family business organizations which should in turn stimulate economy growth. The focus of this article is on the EU regional context of development of family businesses. ${ }^{2}$ Family businesses were mentioned in different EU documents. However, they were in the focus of only a few of them. The first EU document which recognized specific challenges for family businesses and called for improvements in EU Member States is the Commission's Recommendations on the transfer of small and medium-sized enterprises from 1994 [further in text: Recommendations 1994]. ${ }^{3}$ The latest EU document focusing on family business is the European Parliament resolution of 8 September 2015 on family businesses in Europe [further in text: Resolution on family business 2015]. ${ }^{4}$ Author shall discuss recommended measures on the EU level for the Member States together with the relevant studies which analyze the progress and challenges present in the Member States. Development of Croatian businesses, as the newest EU Member State, can be traced from 1990's after the adoption of Companies Act ${ }^{5}$ which introduced modern types of commercial companies. Many Croatian (family) businesses are currently facing the challenge of transfer. The goal is to analyze whether the current state is satisfactory, and to discuss new possible measures which could contribute to the successful transfer of family businesses on both EU and Croatian level.

1 See generally in Fayolle, A.; Kyrö, P.; Ulijn, J.M. (eds.), Entrepreneurship Research in Europe: Outcomes and Perspectives, Edward Elgar Publishing, Cheltenham, 2005

2 Geographical dimension is one of the recognized classifications in studying the entrepreneurship. Zahra, S.A.; Wright, M., Entrepreneurship’s Next Act, Academy of Management Perspectives, vol. 25, no. 4, 2011, pp. 67-83, p. 75

3 94/1069/EC: Commission Recommendation of 7 December 1994 on the transfer of small and medium-sized enterprises, Official Journal L 385, p. 14-17

$42014 / 2210$ (INI)

5 Official Gazette, No. 111/93, 34/99, 121/99, 52/00, 118/03, 107/07, 146/08, 137/09, 125/11, $152 / 11,111 / 12,68 / 13,110 / 15,40 / 19$ 


\section{OVERVIEW OVER THE KEY DOCUMENTS ON THE EU LEVEL REGARDING THE FAMILY BUSINESSES}

It is undisputed that family business is an important factor in EU economy. Despite the obstacles in defining the parameters for family business, ${ }^{6}$ the figures show that at least $60 \%$ of businesses of various sizes in EU are family businesses. ${ }^{7}$ Estimated date shows that family businesses contribute around 50\% of GDP in the EU. ${ }^{8}$ Thus, it is of no surprise that family businesses are an increasing topic in academic research. ${ }^{9}$

As family businesses operate in various company types and sizes, ${ }^{10}$ it can generally be said that they benefit from all policies and actions made by EU bodies which strive to enhance business environment in the EU. Strength of the EU single market and free trade on global and EU level is of high importance for family businesses. ${ }^{11}$ However, family businesses and the specific challenge of transfer of these companies between generations was a focused topic of only a few documents from EU bodies.

We can freely designate the 1990's as the time when the EU bodies recognized the family businesses as a special type of companies with specific challenges. We can mark the Commission's Recommendations 1994 as the beginning of this work. Author shall further analyze this and other EU documents of higher relevance for the EU family businesses.

6 There is still no common definition on the EU level for family businesses, which is a serious obstacle for further development and research of this field. See European Commission, Final report of the expert Group, Overview of Family-Business-Relevant Issues: Research, networks, policy measures and existing studies, November 2009, [further in text: Overview of family businesses study 2009], [https://ec.europa. eu/docsroom/documents/10388/attachments/1/translations/en/renditions/native], accessed 06. April 2020, p. 9

7 Ibid., p. 8. Some claim that this percentage is in fact 70-80\%. European Family Businesses (EFB), Family Business Succession and Transfers: Challenges and Opportunities, 2016, [https:/lec.europa.eu/ transparency/regexpert/?do=groupDetail.groupMeetingDoc\&docid=29616], accessed 20. February 2020

8 European Family Businesses (EFB), [http://www.europeanfamilybusinesses.eu/], accessed 19. February 2020

9 For an overview see in Botero, I. C. et al., Family business research in the European context, European Journal of International Management, vol. 9, no. 2, 2015, pp. 139-159

10 Koeberle-Schmid, A.; Kenyon-Rouvinez, D.; Poza, E. J., Governance in Family Enterprises, Maximizing Economic and Emotional Success, Palgrave Macmillan, New York, 2014., p. 8

11 KPMG\&EFB: European family business barometer, 2019, [http://www.europeanfamilybusinesses.eu/ uploads/Modules/Publications/gm-tl-01172-european-family-barometer-2019_v11_web.pdf], accessed 06. April 2020, p. 39 


\subsection{Commission's Recommendations 1994}

Recommendations 1994 focus on transfer of SME which includes family businesses within this category as well. ${ }^{12}$ It was stressed out that a high number of businesses cease to trade every year because of the obstacles in transfer of the business, where the critical areas are company law, inheritance law and fiscal law of the Member States. ${ }^{13}$ These recommendations put a significant accent on enhancing company law in EU Member states, including all types of companies, from public limited liability companies to partnerships without legal personality. The first set of recommendations for improving company law focuses on availability of public limited liability companies to SME in the process of transfer of the company. The reason behind promoting public limited liability companies is that it is easier to transfer the business from legal aspects within the structure of this company type in comparison to transfer of business within partnerships. ${ }^{14}$ Thus, the Recommendations 1994 request that Member States provide for the transformation of the companies without the need to wind up the firm and to allow for establishment of simplified public limited companies including the possibility that this company has one member only. ${ }^{15}$ The second set of recommendations regards the partnerships and their greatest obstacle for successful transfer: discontinuity due to the death of one of the partners. Thus, the Recommendations 1994 request that Member States provide for a continuity of partnerships in the event of the death of one of the partners, that partnerships agreement have precedence over the terms of the will or a gift of one of the partner and to ensure that after the death of the partner the inheritance law invoking the unanimity for making decisions (consequence of successors becoming joint owners of the shares of the company) do not hamper the continuity of business. ${ }^{16}$

As for the inheritance and tax law, Member States are invited to reduce taxes for inheritance and gifts in the process of transfer of the company, ${ }^{17}$ and to introduce favorable measures for transfer of the company to third persons outside of the family, which includes the employees (e.g. by delaying the necessary fiscal payments in case of a transfer). ${ }^{18}$

\footnotetext{
12 Successful transfer of family business is set as one of the goals in the Article 1 of Recommendations 1994

13 See Preamble of the Recommendations 1994

14 Loc. cit.

15 Subparagraphs a), b) and c) of article 4 of the Recommendations 1994

16 See Article 5 of the Recommendations 1994

17 See Article 6 of Recommendations 1994

18 See Article 7 of Recommendations 1994
} 
Besides these recommendations, European Commission called for some soft law measures as well. For example, Member States are encouraged to raise awareness of business transfer problem to entrepreneurs so that they start with the preparations on time. ${ }^{19}$ Also, they are encouraged to provide a supporting financial environment for business transfer. ${ }^{20}$

Although this document was drafted 26 years ago, in author's opinion, its recommendations are contemporary and applicable nowadays as well. In fact, it demonstrates that the needs of these companies remained the same, and EU Member States should continue acting in the directions set forth in this document.

Notably, Member States were obligated to report on the measures adopted in order to adhere to the Recommendations $1994 .{ }^{21}$ Since then there were several reports which also contributed to the discussion of how to further enhance the transfer of family businesses in EU.

\subsubsection{8 - First Report after the Commission's Recommendations 1994}

The Commission issued the report in 1998 in a new document called Communication from the Commission on the transfer of small and medium-sized enterprises [further in text: First Report 1998]..$^{22}$ The main conclusion was that there are still significant differences in Member States regarding the transfer of the business, and that the Recommendations 1994 were not sufficiently followed. However, it was stated that most of the measures introduced by the Member States concerned the civil and company law issues, while less so for the fiscal and inheritance law. ${ }^{23}$ In the report, there are comparative tables which show for each Member State which measures recommended by the Recommendation 1994 were accepted and which was not. ${ }^{24}$

\footnotetext{
19 See Article 1 of Recommendations 1994

20 See Article 3 of Recommendations 1994

21 This report was eagerly awaited. There were two written questions (from the same person) to the Commission demanding the answer of whether the EU Member States reported on the progress of their legislation in line with the Recommendations 1994. See Written Question No. 235/96 by Concepció FERRER to the Commission, Transfer of enterprises, OJ C 137, 8.5.1996, p. 50; Written question No. 2016/96 by Concepció FERRER to the Commission, Transfer of small and medium-sized enterprises, OJ C 385, 19.12.1996, p. 78

22 Communication from the Commission on the transfer of small and medium-sized enterprises, OJ C 93, 28.3.1998, p. 2-12

23 See First Report 1998, p.3

24 See First Report 1998, p. $13-21$
} 
There are laso improvements of the Recommendations 1994, partially based on examples of good experience from the practice in various Member States. Regarding the continuity of the company, Member States are encouraged to consider following measures: pre-emption right of the heir working in the business to buy the shares from other heirs not working in the business, use of family constitutions (family protocol, Familienverfassung) ${ }^{25}$ to avoid possible conflicts in transfer of the business between generations, simplification of administrative procedures for the transfer of business, tax neutrality for the conversion of the company in preparation of transfer and other. ${ }^{26}$

Special focus is put on "support measures" by the work of consultants and financial institutions for transfer of the business. Consultants should offer varying services to the companies in transfer of business, providing the professional advice before, during and after the transfer of the business. The experiences from the successful transfers clearly show that transferor must be aware of the need to arrange the transfer plenty time before the actual transfer and that the transferee must be familiarized with the company on time (transferor could even help the transferee for a certain time period after the actual transfer). ${ }^{27}$ As for the financing part, the acquisition of the existing company is more expensive, could be even around $60 \%$ higher then starting the company from the beginning. Thus, examples of good practice are preferential interest rates for loans facilitating business transfers, schemes providing guarantees for business acquisition and other. ${ }^{28}$ Lastly, we would like to emphasize the report recognized the existence of the databases - networks for potential buyers and sellers as a helpful instrument in transfer of business when such a transfer is not possible within the family or towards the employees. ${ }^{29}$

It can be concluded that the goal of the First Report 1998 was to encourage the Member Statfurther implement the Recommendations 1994, by also providing some examples of good practice to serve as an inspiration.

25 See more about family constitution in Braut Filipović, M., Obiteljski ustav - instrument za stvaranje obiteljske i poslovne strategije u obiteljskim društvima, in: Slakoper, Z.; Bukovac Puvača, M.; Mihelčić, G. (eds.), Liber Amicorum Aldo Radolović, Sveučilište u Rijeci, Pravni fakultet, Rijeka, 2018, str. 529-550

26 See First Report 1998, p. 5 - 7

27 See First Report 1998, p. $9-10$

28 See First Report 1998, p. 8 - 9

29 See First Report 1998, p. 10 


\subsubsection{2 - Second Report after the Commission's Recommendations 1994}

The second report after Recommendations 1994 came from the European Commission in 2002 in the form of the Final report of the Expert Group on the Transfer of Small and Medium-sized Enterprises [further in text: Second Report 2002]..$^{30}$ The report concludes that the overall result in implementing Recommendations 1994 is still not satisfying, although each Member State adopted certain measures. Still, no measures had been taken regarding more that half of the recommendations. ${ }^{31}$

Among other, special attention in the report is put on the presentation and analysis of the databases for connecting potential buyers and sellers in the Member States. ${ }^{32}$ It is considered as a good example of creating the transfer market for those who don't have obvious successor of their business. Although the data had changed from the time this report was written, we find nowadays examples of these databases as well. For example in Austria ${ }^{33}$ and in Germany. ${ }^{34}$

Considering the report's assessment that current state in Member States regarding the transfer of the business should be improved, it proposed six additional measures to facilitate this goal: creation of a "European Business Transfer Centre", Creation of European sellers and buyers database/market place, organization of regular European seminars/meetings, development of additional training and management tools, public initiated support programs and research, and achieving equal attention to start-ups and transfers. ${ }^{35}$ Till this day, the first two measures are not fulfilled, while the others are at the best fragmented achievements by mostly private initiatives, as shall be further discussed in the article.

\subsubsection{3 - Third Report after the Commission's Recommendations 1994}

Just a year after the Second report 2002, European Commission issued a new report within the follow-up project in the document called Transfer of businesses

\footnotetext{
30 [https://ec.europa.eu/docsroom/documents/2158/attachments/1/translations/en/renditions/native], accessed 22. March 2020

31 Second Report 2002, p. 6

32 Second Report 2002, p. 25. In 2006 there was a research on the existence and how to enhance these databases. See European Commission, Fostering Transparent Marketplaces for the Transfer of Businesses in Europe, Report of the Expert Group, 2006

33 Nachfolgebörse, [www.nachfolgeboerse.at], accessed 22. March 2020

34 Nexxt-Change Unternehmensbörse, [www.nexxt-change.org], accessed 22. March 2020

35 Second Report 2002, p. 44-45
} 
- continuity through a new beginning in $2003 .{ }^{36}$ This report agreed with all the findings of the previous reports. Its main goal was to further encourage the Member States to changes in line with the Recommendations 1994.

\subsubsection{6 - Fourth Report after the Commission's Recommendations 1994}

In 2006 the European Commission issued yet another and the last report which reflects the state of measures adopted in Member States following the Recommendations 1994. ${ }^{37}$ Fourth Report 2006 starts with a general conclusion that only in about $55 \%$ of the proposed measures are adopted in Member States. ${ }^{38}$ However, there are certain improvements across the Member States, in particular regarding the possibility to establish small businesses in the form of the limited liability companies (with just one member), continuity of partnerships after the death of one of the partners if the possibility is drafted in the partnership agreement, possibility to change the legal form to ease the transfer of the business and inheritance taxes are abolished or reduced for the transfer of the business between the family members in many countries. Areas which are still insufficiently developed are primarily financial support to businesses in the process of transfer and introduction of favorable taxes for transfer of the business to third person (outside of the family) and to employees. ${ }^{39}$

This report focuses on the recommendations for Member States to give equal political attention to business transfers as to start-ups, to provide adequate financial support, to raise awareness for the timely preparation of the business transfer, to organize markets for potential buyers and sellers of the businesses, to introduce more favorable tax rules for the business transfers and to create appropriate structures on national, regional and local level to support the administration of the business transfers. ${ }^{40}$

This report, which came twelve years after the Recommendations 1994, was the last report regarding the implementation of the Recommendations 1994. Further documents regarding the transfer of the business, including family businesses, do not longer analyze the effect of Recommendations 1994 on national legislations and other measures of Member States.

\footnotetext{
36 European Commission, Final report of the MAP 2002 project, August 2003, [https://www.cbs.dk/files/ cbs.dk/best_report-08-2003_3667.pdf], accessed 26. March 2020

37 Communication from the Commission to the Council, the European Parliament, the European Economic and Social Committee and the Committee of the Regions, Implementing the Lisbon Community Programme for Growth and Jobs, Transfer of Businesses - Continuity through a new beginning, COM (2006) 177 final, Brussels, 2006 [further in text: Fourt report 2006]

38 Fourth Report 2006, p. 5

39 Fourth Report 2006, p. 6-8

40 Fourth Report 2006, p. 9-10
} 


\subsection{Small Business Act from 2008}

The Small Business Act from $2008^{41}$ represents an initiative by the Commission to improve the position of SME in the EU internal market. ${ }^{42}$ It introduces a "think small first" policy, which means that legislators should bear in mind the special needs of SMEs when shaping their policy. ${ }^{43}$ The Small Business Act consists of the set of principles which should be turned into policy action on both EU and national levels. Family businesses are often considered to fall within the category of SMEs. Thus, it is not surprising that in the very first principle the Commission encouraged the creation of "environment in which entrepreneurs and family businesses can thrive", ${ }^{44}$ together with some sort of guidelines how to achieve this goal. The biggest accent is put on education and mentoring of the future and current entrepreneurs followed by ensuring favorable taxes for the business transfers and introducing databases for connecting buyers and sellers of businesses. ${ }^{45}$ Besides these guidelines which are in line with the Recommendations 1994, this time the Commission added two new goals and that would be the support for female entrepreneurs and for immigrants who wish to become entrepreneurs.

The Small Business Act was eagerly awaited and the crucial benefit from it should have been the legislative proposals on both EU and national levels which would implement the principles encouraged in the act. ${ }^{46}$ The successful example of the adopted legislation would be the Late Payment Directive. ${ }^{47}$ On the opposite side, the Proposal for a European Private Company was revoked. ${ }^{48}$ Interestingly, regarding the improvement of tax system for SMEs it was not until 2018 that there was

41 Communication from the Commission to the Council, the European Parliament, the European Economic and Social Committee and the Committee of the Regions - "Think Small First" - A "Small Business Act" for Europe, COM/2008/0394 final

42 It was followed up by the European Parliament resolution of 10 March 2009 on the Small Business Act, OJ C 87E , 1.4.2010, p. 48-59

43 About the „think small first“ principle see an overview with the suggestions how to implement it in EU legislations in European Commission, Report of the Expert Group, Thinks Small First - Considering SME interests in policy-making including the application of an "SME Test", March 2009, [https://ec.europa.eu/ docsroom/documents/2664/attachments/1/translations/en/renditions/native], accessed 26. March 2020

44 Small Business Act, p. 4

45 Small Business Act, p. 6

46 See the list of legislative proposals connected with the achievement of the goals set in principles in Small Business Act, p. 4

47 Directive 2011/7/EU of the European Parliament and of the Council of 16 February 2011 on combating late payment in commercial transactions, OJ L 48, 23.2.2011, p. 1-10

48 Proposal for a Council Regulation on the statute for a European private company, COM/2008/0396 final 
a proposal for introducing special scheme for SMEs. ${ }^{49}$ The European Parliament issued many resolutions connected with the fulfillment of the goals set in the Small Business Act. ${ }^{50}$

However, ten years after, the Small Business Act failed to achieve the high goals set in it. Thus, there are calls to make the principles legally binding in order to provoke coordinated action on EU and national level. ${ }^{51}$

\subsection{Overview of family-business-relevant issues study from 2009}

A new project funded by the European Commission resulted in a Overview of family businesses study 2009. The major contribution of this study is the proposal of definition of family business which should serve as a starting point in recognizing specific needs and in shaping any policies towards family businesses on EU and on national level. Family businesses are defined as those where majority of decision-making rights (indirect or direct) belong to person who established the company or his family, and where at least one family member is involved in the governance of the business/company. ${ }^{52}$ However, the proposed definition is not legally binding but rather influential for further legislative proposals.

This study is also the first one on the EU level which reflects upon unique challenges of corporate governance in the family businesses. ${ }^{53}$ The balance between the family and business, especially in the transfer of business between the generations, is the test of survival for these businesses. Thus, the study emphasizes the good examples of soft law tools which could help with the challenges in the corporate governance of family businesses, which is in the scholarly writings described as the "family governance". ${ }^{54}$ The level of recognition of the family governance instruments and their application is high in some Member States, while practically

\footnotetext{
49 Proposal for a Council Directive amending Directive 2006/112/EC on the common system of value added tax as regards the special scheme for small enterprises, COM/2018/021 final

50 See for example European Parliament resolution of 5 February 2013 on improving access to finance for SMEs, OJ C 24, 22.1.2016, p. 2-7

51 See Opinion of the European Economic and Social Committee on 'Promoting SMEs in Europe with a special focus on a horizontal legislative SME approach and respect of the SBA's "think small first"' (exploratory opinion), OJ C 197, 8.6.2018, p. 1-9

52 Overview of family businesses study 2009, p. 10

53 Overview of family businesses study 2009, p.16. For an academic overview see for example Groth, T. $e t$ al., Familienunternehmen, Erfolgsstrategien zur Unternehmenssicherung, Feutscher Fachverlag, Frankfurt am Main, 2012.; Kormann, H., Governance des Familienunternehmens, Springer, eBooks, Wiesbaden, 2017

54 Koeberle-Schmid; Kenyon-Rouvinez; Poza, op. cit., note 10, p. 11
} 
nonexistent in others. ${ }^{55}$ This study provided for some good examples in order to inspire national governments and private-sector organizations in representing and advocating these tools to family businesses.

Pertaining to the challenges of the family businesses is also a lack of skilled workforce, due to the negative image of family businesses in the labor market. ${ }^{56}$ The negative picture stems from the notion that non-family members don't have the same opportunity as the family members. Other challenges recognized in this study are the ones already elaborated in the previous EU documents analyzed in this article.

The overall conclusion of the study is that further positive development depends heavily on the awareness of the policy makers of the specific need and challenges of the family businesses on both the EU and national level. ${ }^{57}$

\subsection{Entrepreneurship 2020 Action Plan}

European Commission's Entrepreneurship 2020 Action Plan for the period 2013$2020,{ }^{58}$ proposes policy initiatives for improving conditions for operating successful business in Member States. The goal of this article is not to analyze all presented measures. It suffices to be said that challenges of transfer of the family business were appropriately recognized, ${ }^{59}$ and that Member States are once again called to reconsider tax policy for business transfers. ${ }^{60}$ Regarding the SMEs, and thus the majority of family businesses, it reinforces the objectives set in the Small Business Act.

\subsection{European Parliament Resolution on family businesses in Europe from 2015}

The last document on the EU level regarding the challenges of transfer of family businesses is the European Parliament Resolution of family business 2015. In its resolution the European Parliament stated that even after more than five years from the Overview of family businesses study 2009, there is no new initiative on the EU level regarding the transfer of family businesses. ${ }^{61}$ There is even no common definition of what the family business is on the EU level till today.

\footnotetext{
55 Overview of family businesses study 2009, p.16

56 Overview of family businesses study 2009, p.17

57 Overview of family businesses study 2009, p. 24

58 Communication from the Commission to the European Parliament, The Council, The European Economic and Social Committee and the Committee of the Regions, Entrepreneurship 2020 Action Plan Reigniting the entrepreneurial spirit in Europe, COM/2012/0795 final

59 Entrepreneurship 2020 Action Plan, p. 15

60 Entrepreneurship 2020 Action Plan, p. 17

61 Preamble, no. J of Resolution of family business 2015
} 
The resolution starts with the explanation of how the family businesses contribute to economy and employment in the Member States. It calls again for ensuring more favorable funding conditions regarding taxes and various sources of funding either through EU or national programs for support of these businesses or through alternative sources of financing. The resolution also points to the need of internationalization and innovation of family businesses, calling for incentives to take risks for business growth together with staff training and use of professionals outside of the family. ${ }^{62}$ Among other, it also calls for ensuring education on business transfer and family governance. ${ }^{63}$ The general motive of the resolution is to call the European Commission on issuing new measures which would fulfill the goals already set by previous EU documents and eagerly reinforced by this resolution.

\subsection{Concluding remarks}

Importance of family businesses and their challenges, primarily concerning the business transfer, are definitely recognized in various documents on the EU level. These documents offered possible answers for enhancing the position of family businesses. However, what they all have in common is that they are not legally binding. They represent soft law instruments, primarily recommendations and examples of good practices which should have positive influence and encourage the Member States for their implementation. The crucial document so far is the Recommendations 1994. However, it remains an open issue whether these recommendations are adopted in Member States, and if they are, to what degree.

\section{CROATIAN FAMILY BUSINESSES - CURRENT STATE AND SPECIFIC CHALLENGES}

Croatian family businesses face the same challenges as family businesses in other countries. ${ }^{64}$ There are no official statistics regarding the number of the family business in Croatia. ${ }^{65}$ In the literature we find that it is presumed that $50 \%$ of

62 No. 18 of Resolution of family business 2015

63 No. 21 of Resolution of family business 2015

${ }^{64}$ For some reflections on legal challenges of business transfers between the generations see an overview in Cikać, V., Pravni aspekti nasljedivanja obiteljskih poduzeća u Hrvatskoj, CEPOR, 2012, [http:// www.cepor.hr/news/obiteljska-poduzeca/CEPOR_policy\%20osvrt_Pravni\%20aspekti\%20nasljedjivanja\%20obiteljskih\%20poduzeca\%20u\%20Hrvatskoj.pdf], accessed 08. April 2020

65 According to one study, at least $38 \%$ of businesses whose owners are 55 years old or more fall within the frame of family businesses, with the tendency to increase these numbers. Alpeza, M.; Grubišić, N.; Mikrut, M., Business Transfer Barometar Hrvatska, Centar za politiku razvoja malih i srednjih poduzeća i poduzetništva (CEPOR), Zagreb, 2015., str. 21 
employees are employed in family businesses in Croatia, ${ }^{66}$ which is in line with the numbers on the EU level. However, there is at least one defining factor which puts them apart from others. It is the fact that Croatian companies, including family businesses, were mostly established in 1990's, and the first owners are now for the first time facing the challenge of transfer of family business. ${ }^{67}$ Thus, Croatian companies face the challenge of managing and transferring the family businesses and there is no or few domestic practice to guide them. ${ }^{68}$

In the EU documents regarding the analysis of family businesses, Croatia was first included in the Overview of family businesses study 2009, as a candidate country. Thus, there are no official data on the status of Croatia regarding the Commission Recommendations 1994. In fact, there are a very small number of studies on family businesses in Croatia. Practically all studies belong to private initiatives. We shall use the results of those which are publicly available in order to provide a more accurate assessment of family businesses in Croatian economy. As to the academic literature, the interest regarding the family businesses is present for about fifteen years, but it is rather sporadic and mostly engaged by economic scholars.

The general conclusion we find in literature is that there is no systematic policy to support Croatian family businesses. ${ }^{69}$ The goal in this article is to present some initiatives and current legal and fiscal regulations in order to provide a more coherent picture of the existing environment for family businesses in Croatia.

\subsection{Is there a definition of family business in Croatia?}

There is no definition of family business in Croatia. ${ }^{70}$ Croatian Companies Act does not recognize family business as a special type of company. On the other hand, family businesses are mentioned in the Crafts Act, ${ }^{71}$ but only in the context that members of the family household can support the craftsman in carrying out

${ }_{66}$ CEPOR, Razvoj i održivost obiteljskih poduzeća u Hrvatskoj, 2012 [http://www.cepor.hr/news/obiteljska-poduzeca/FB_policy\%20brief_CEPOR.pdf], accessed 06. April 2020, p. 5

${ }_{67}$ It's the same for other ex-Yugoslavia countries. For example, see for Slovenia in Duh, M., Family Businesses: The Extensiveness of Succession Problems and Possible solutions, in: Burger-Helmchen, T. (ed), Entrepreneurship - Gender, Geographies and Social Context, IntechOpen, 2012, pp. 209-234, p. 211

68 Senegović, I.; Bublić, V.; Ćorić, G., Family Business Succession Risks: the Croatian Context, in: Dana, L-P.; Ramadani, V. (ed.), Family Businesses in Transition Economies, Management, succession and Internationalization, Springer, 2015, pp. 175-199, p. 181

69 See for example Crnković Pozaić, S., Overview of Family Business Relevant Issues, Country Fiche-Croatia, CEPOR, 2008, [http://www.cepor.hr/cepra/wp-content/uploads/2015/07/Family-Busines_country_fiche_Croatia_en.pdf], accessed 02. April 2020, p. 1

70 See: Alpeza; Grubišić; Mikrut, op. cit., note 65, p. 14

${ }_{71}$ Official Gazette, No. 143/13, 127/19 
crafts activities without the need of concluding the employment contract. ${ }^{72}$ The same exception is allowed for family members of the holder of the family farms in Croatian Family Farms Act. ${ }^{73}$ These favorable measures speak of recognition of the importance of family context in these types of economic activities. In fact, in Croatian literature it is generally considered that family businesses are the most represented in agricultural sector, tourism and crafts. ${ }^{74}$

However, they represent fragmented examples and are not a part of a structured policy towards family businesses. ${ }^{75}$ The Overview of family businesses study 2009 clearly pointed out that the definition of what constitutes the family business is a crucial step for developing appropriate policy on national level. ${ }^{76}$ The same was concluded in Croatian study Business Transfer Barometar Hrvatska 2015, and most importantly, this study proposed adopting the same definition as drafted on the EU level by the Overview of family businesses study $2009 .{ }^{77}$ It is a good example of how private initiatives put an effort to guide the Croatian legislatures in the direction set by the EU for further development of family businesses. However, even eleven years after the definition was proposed on the EU level and five years after the same was done in Croatia, no results can be seen in relevant documents of the policy makers.

\subsection{Public and private initiatives for increasing awareness, information and training of entrepreneurs from family business}

Raising awareness of the challenges which family businesses face is in the core of all the EU documents relevant for this topic. It is necessary to raise awareness of their needs to both entrepreneurs who fit in the category of family businesses and to public bodies which can introduce policies to support these businesses.

\footnotetext{
72 Article 30 of the Crafts Act. For analysis of such an exception see Senčur Peček, D.; Laleta, S., Ugovor o radu i ugovor o djelu: područje primjene radnoga zakonodavstva, Zbornik Pravnog fakulteta Sveučilišta u Rijeci, 2018, vol. 39. no. 1, pp. 411-456, p. 424

73 Article 25 of the Family Farms Act, Official Gazette, Nos. 29/18, 32/19

74 In a study conducted in 2007 among the entrepreneurs who applied for financing from the Croatian Bank for Reconstruction and Development - HBOR, the leading sector for family businesses was agricultural sector (47,33\%) followed by tourism (38,87\%). See Renko, N.; Kuvačić, D.; Renko, S., Analiza empirijskog istraživanja o obiteljskom poduzetništvu u Republici Hrvatskoj, Ekonomski pregled, vol. 58. no. 1-2, 2007, pp. 72-90, p. 84. See also Crnković Pozaić, op. cit., note 69, p. 3

75 See Senegović; Bublić; Ćorić, op. cit., note 68, p. 181

76 Overview of family businesses study 2009, p. 10

77 See Alpeza; Grubišić; Mikrut, op. cit., note 65, p. 9
} 
As to the education of entrepreneurs, there are a few courses focused exclusively on family businesses in faculties of economics, though not in all. ${ }^{78}$ They are not considered at all in the faculties of law, ${ }^{79}$ except by the individual professors as a fragmentary topic within other courses. If not within the faculty, future entrepreneurs can obtain knowledge through other form of education, as for example various workshops and conferences on the topic of family businesses. In Croatia, such events are organized by private initiations. Further, EU documents emphasize that consultancy services can also contribute to raising awareness to entrepreneurs and to provide the knowledge to successfully overcome the challenges of family businesses. There are more consultancy firms who provide the services to family businesses on the Croatian market. ${ }^{80}$ Thus, we can conclude that there are certain sources of transfer of knowledge through education. However, it is mostly done through private initiatives and services while public sources should encourage this topic at least throughout public faculties, especially on faculties of economics and law.

The most active organization in Croatia which supports the family businesses is SMEs and Entrepreneurship Policy Center - CEPOR. ${ }^{81}$ CEPOR is a non-profit organization which is founded in 2001 by cooperation between academic and entrepreneurships institutions. Its main goal is to promote the needs and importance of SMEs in the Croatian economy, thus influencing the policy makers. Within CEPOR, a special body was constituted, the so-called Center for Family Businesses and Business Transfer - CEPRA, ${ }^{82}$ as an educational and informative center for the business transfer and other challenges of family businesses. Their work resulted in important studies, such as Business Transfer Barometar Hrvatska from 2015 and Izazovi prijenosa poslovanja u malim $i$ srednjim poduzećima from $2017^{83}$ which results are used in this article. Additionally, there are brochures/guides ${ }^{84}$ and many workshops organized in order to raise awareness of the challenges of family busi-

78 See for example the course "Obiteljsko poduzetništvo" in the Faculty of Economics in Osijek, [http:// www.efos.unios.hr/obiteljsko-poduzetnistvo/opis-kolegija/], accessed 09. April 2020

79 The exception is the Postgraduate specialist study programme in Corporate Finance Law at the University of Rijeka, Faculty of Law, [https:/pravri.uniri.hr/en/study-programmes/corporate-finance-law. html], accessed 09. April 2020

80 The example which should be brought forward is a consultant who recently wrote a book about challenges of family businesses in the countries of ex-Yugoslavia, with many interesting suggestions and personal finding on this matter. See Vukić, B., Osnivači, nasljednici, menadžeri, Beletra, Zagreb, 2019

81 The official webpage is CEPOR, [https://www.cepor.hr/], accessed 02. April 2020

82 The official webpage is CEPRA, [http://www.cepor.hr/cepra], accessed 02. April 2020

83 Mezulić Juric, P.; Alpeza, M., Izazovi prijenosa poslovanja u malim i srednjim poduzećima, CEPOR, Zagreb, 2017

84 The newest one from 2019 is written in a form of a guide with a lot of valuable counsels for family businesses in the process of business transfer. See CEPOR, Minivodic za poduzetnike, Prijenos poslovan- 
nesses and to provide counsel to these entrepreneurs within the CEPOR. ${ }^{85}$ The importance of family businesses is recognized in a few other private initiatives. ${ }^{86}$

The importance of family businesses is recognized on the government level through various rather informal activities. ${ }^{87}$ However, there is no clear policy in its strategic documents, as some recognize the family businesses with their importance and specific challenges ${ }^{88}$ while others remain completely mute on the matter. ${ }^{89}$ There were also some funding programmes available to entrepreneurs which were certainly of the interest to family businesses as well, which we shall elaborate further in text. Still, the public policy towards family businesses remains sporadic, although it seems that their importance for Croatian economy is recognized.

\subsection{Supportive financial environments for successful business transfers}

In Croatian practice, there were more financial programmes which provided access to finance under favorable terms for entrepreneurs. The main national organizations providing these programmes are the HBOR (Croatian Bank for Reconstruction and Development) and HAMAG-BICRO (Croatian Agency for Small Business, Innovation and Investments). These organizations work closely with other banks in Croatia in order to successfully realize such programmes. Some of the available financial schemes are funded directly by the EU financial programmes such as $\mathrm{COSME}^{90}$ and different projects from the European Investment Bank. ${ }^{11}$ The focus is on providing the entrepreneurs with favorable loans or providing a guarantee which is necessary for obtaining bank loans. However,

ja, 2019., [https://www.mingo.hr/public/Minivodic_CEPOR_web\%202019.pdf], accessed 04. April 2020

85 For list of workshops see in webpage: Radionice za obiteljska poduzeća, CEPOR, [https://www.cepor. $\mathrm{hr} /$ edukacije/radionice-za-obiteljska-poduzeca/], accessed 03. April 2020

86 See for example the list of conferences on the topic of family business organized throughout the years by LIDER - business journal, [https://lider.events/obiteljske/arhiva/], accessed 04. April 2020

87 See for example participation of the Ministry of the Economy, Entrepreneurship and Crafts in conferences with the aim to stress out the importance of family businesses for the Croatian economy, [https:// www.mingo.hr/], accessed 04. April 2020

88 See for example Ministarstvo poduzetništva i obrta, Akcijski plan za provedbu Strategije razvoja poduzetništva žena u Republici Hrvatskoj 2014.-2020., [https://www.mingo.hr/public/Poduzetnistvo/ Akcijski_plan_provedbe_Strategije_razvoja_poduzetnistva_zena_RH12117.pdf], accessed 09. April 2020

89 See for example Ministarstvo poduzetništva i obrta, Strategija razvoja poduzetništva u Republici Hrvatskoj 2013.-2020., [http://www.europski-fondovi.eu/sites/default/files/dokumenti/Strategy-HR-Final. pdf], accessed 09. April 2020

90 For an overview see COSME, [https://ec.europa.eu/growth/smes/cosme_hr], accessed 10. April 2020

${ }_{91}$ For an overview see European Investment Bank, [https://www.eib.org/en/projects/regions/european-union/croatia/index.htm], accessed 10. April 2020 
these programmes were not aimed to family businesses exclusively, but to groups of entrepreneurs as are SMEs and other. Croatian family businesses can thus use this programmes if they fall within categories of entrepreneurs as defined by the programmes.

As to the transfer of the business, the first financial scheme with the exclusive goal to support the successful business transfer in cases when the business is being sold to a third person became available in the first half of 2019. The new PLUS Guarantee Program for Croatian Entrepreneurs was introduced by HAMAG-BICRO. ${ }^{92}$ The guarantee scheme functions in a way that the HAMAG-BICRO gives a guarantee to entrepreneurs for the purchase of $100 \%$ equity of the business in transfer in the amount up to $60 \%$ or $80 \%$ of the purchase price. This guarantee is of crucial importance to the entrepreneurs who seek the bank loan for buying the business. Its creation was influenced by the work of CEPOR, which shows how important are the work of such organizations on development of national policy towards challenges of business transfers. Again, this financial scheme was not created for family businesses exclusively, but it is clear that owners of Croatian family businesses could benefit from it.

\subsection{Measures inserted in company law which support the continuity of business after the transfer}

Croatian company law is relatively young, as the current types of companies are introduced in 1995 by the Companies Act. The advantage is that Croatian legislature inserted modern solutions, without going through tedious processes of change as much older comparative legislations. The initial presumption is that this means that Croatian solutions are more in line with the Recommendations 1994 as it could show more flexible solutions due to its youth.

Croatian family businesses can be formed in any legal forms available to entrepreneurs. Interestingly, in a research conducted in 2007 on the sample of family businesses who applied for funding projects within the $\mathrm{HBOR}$, most family businesses were in the legal form of a craft $(38,57 \%)$, followed by limited liability companies $(19,87 \%) .{ }^{93}$ Generally, Croatian entrepreneurs often choose crafts as their type of business. $^{94}$

92 Jamstveni program PLUS, [https://hamagbicro.hr/financijski-instrumenti/kako-do-jamstva/msp/nacionalna-jamstva/plus/], accessed 04. April 2020

93 Renko; Kuvačić; Renko, op. cit., note 74, p. 82

94 In 2019 the official statistic shows that from all the businesses, the crafts were represented by $38,8 \%$ and commercial companies by $61,2 \%$. See Trgovačka društva i obrti, [https://www.hok.hr/gospodarstvo-i-savjetovanje/statistika/trgovacka-drustva-i-obrti], accessed 10. April 2020 
In Croatian law, we can distinguish between the partnerships without legal personality (ortaštvo), ${ }^{95}$ partnerships with legal personality (general and limited partnerships), ${ }^{96}$ companies (joint-stock and limited liability companies) ${ }^{97}$ and crafts.

Partnerships are significantly more sensitive regarding any change concerning partners. For both partnerships with and without legal personality, the main rule is that the transfer of the share to third person is not possible unless other partners unanimously agree. ${ }^{98}$ However, Croatian Obligations Act and Companies Act provided for different default solutions regarding the continuity of business, where the common part is that parties are free to provide for different outcomes in their partnership agreements. For the partnership without legal personality (ortaštvo), after the death of the partner, the Obligations Act provides that the partnership continues with other partners (unless it was a two-member partnership). ${ }^{99}$ In other words, the presumption is that the partnership (ortaštvo) shall continue to exist if one of the partners dies or ceases to exist. The heirs can inherit the share only if provided so by the partnership agreement. ${ }^{100}$ On the other hand, for the partnerships with legal personality, if a partner dies or ceases to exist or exits the partnership, the consequence is that the partnership ceases to exist as well, unless partners insert in their articles of association that the partnership shall continue to exist with remaining partners in such cases. ${ }^{101}$ What is very important, even if there is no such a provision originally, after the death of one partner the others can bring a decision to continue the business. ${ }^{102}$ Thus, there are options for both transfer and continuity of business for partnerships, although partners should be aware of the described specific legal solutions for each type.

95 They are called "Ortaštvo". See articles 637-660 of the Obligations Act, Official Gazette, No. 35/05, $41 / 08,125 / 11,78 / 15,29 / 18$

96 General partnerships are called „Javno trgovačko društvo" (articles 68-130 of Companies Act), and limited partnerships are called „Komanditno društvo“ (articles 131-147 of Companies Act). Besides these two types of partnerships, another company was introduced under the influence of EU legislation, the Economic Interest Grouping (Gospodarsko interesno udruženje) which shares some basic features with partnerships (see articles 583-609 of Companies Act)

${ }_{97}$ Joint-stock companies are called „Dioničko društvo“" (articles 159-384.c of Companies Act) and limited-liability companies are called „Društvo s ograničenom odgovornošću“ (articles 385-472.h of Companies Act)

98 Article 641 (5) of the Obligations Act. See also Barbić, J., Pravo društava, Društva osoba, Organizator, Zagreb, 2019, p. 65. See also Article 90 of the Companies Act

99 Article 655 of the Obligations Act. See also Barbić, ibid., p. 68

100 Article 656 of the Obligations Act

101 Article 104 of the Companies Act

102 Barbić, op. cit., note 98, p. 541 
Joint-stock and limited liability companies allow for free transfer of shares to third persons, unless otherwise provided in the articles of association, ${ }^{103}$ and the change of shareholders (death or exit from the company) has no impact on the existence of the company.

The transfer of the craft is more complicated. In fact, the Crafts Act does not even provide for an option of the sale of the crafts to the third person. ${ }^{104}$ So, for the actual transfer, the craftsman must firstly enter into a partnership agreement with a new partner, ${ }^{105}$ which will allow them to run the business together. After that the original craftsman can exit the craft, and the craft shall continue with the remaining partner. ${ }^{106}$ So, the transfer is rather complicated, but it is possible. After the retirement or death of the craftsman, the members of the family have the choice to inherit the craft and continue the business. However, the heirs must obtain the necessary qualifications through education degrees or master craftsman's examination. The other option for heirs is to hire an employee which fulfills the requested criteria by the Crafts Act. ${ }^{107}$

Thus, family business in Croatia enjoys a good legal framework for ensuring the continuity of their businesses. Joint-stock and limited liability companies offer the simplest solutions for transfer and continuity of business, but with careful legal drafting it is possible to ensure the same with partnerships and crafts.

As to the flexibility of the company law to adjust to the needs of the family businesses, we shall point to two main findings: availability of joint-stock and limited liability companies for all sizes of family businesses regardless of the number of shareholders, and possibility to transform between the legal forms of the companies.

Both joint-stock and limited liability companies can have more or just one shareholder. ${ }^{108}$ By far the most popular company type in Croatia is the limited liability company (over 98\%). ${ }^{109}$ Additionally, from 2012 entrepreneurs can opt for a simplified limited liability company with the share capital of only $10 \mathrm{KN}$ (cca 1,3 Euro) which in comparison to regular limited liability companies is more simple

\footnotetext{
103 Article 227 and article 412 of the Companies Act

104 See also CEPOR, op. cit., note 84, p. 35

105 Article 33 of the Crafts Act

106 Article 35(2) of the Crafts Act

107 Articles $37-40$ of the Crafts Act. For the criteria which must be fulfilled by the heirs see articles 8-9 of the Crafts Act

108 Article 159 (2) and article 386 of the Companies Act

109 Croatian Bureau of Statistics, Number and structure of business entities, September 2019, [https://www. dzs.hr/], accessed 13. April 2020
} 
for establishing. ${ }^{110}$ The limited liability company is considered to be so popular due to more reasons. But one of the most commonly suggested is the high autonomy of the parties to arrange their internal relations due to many dispositive provisions, ${ }^{111}$ less formality in the functioning of the company and other.

As to the transformation of the companies, the procedure for transformation of the partnerships with legal personality (general and limited partnership) to jointstock and limited liability companies and vice versa is provided for in the Companies Act. The companies in transformation don't go into liquidation and the transformed company remains the same legal person, just a different type of the company. ${ }^{112}$ However, there is no such procedure for partnerships without legal personality (ortaštvo) and for crafts. This means that their transformation is left to contractual drafting and that these businesses must cease to exist. The founders must establish a new business or transfer the business by contract to the already existing company, where legal consequences and continuity of obligations between the old and the new business is left entirely to obligations law and drafting of the contract between the interested parties. Also, these transfers can cause some serious tax consequences for the parties. Thus, the transformation of the partnerships without legal personality (ortaštvo) and crafts poses more legal and financial challenges then for other types of businesses in Croatia.

To conclude, the Croatian company law has many modern and flexible solutions for functioning of family businesses and for business transfers. Still, family businesses should seek the professional advice and use to the maximum possibilities to arrange the relations within the partnership/company/craft to the best of their interest. We believe that the awareness of the family of the fact of what they can do is currently more important then changing already existing legal forms for doing business in Croatia.

\subsection{Favorable tax treatment for business transfers}

When considering the tax aspects of transfer of Croatian family businesses, we must distinguish two situations: when the transfer occurs among the family members and when the business is transferred to third persons. ${ }^{113}$

110 Article 390.a of the Companies Act. See also Jurić, D., Pravo društava, Pravni fakultet Sveučilišta u Rijeci, Rijeka, 2020, p. 402

111 Barbić, J., Pravo druśtava, Društva kapitala, Svezak II.: društvo s ograničenom odgovornošću, društvo za uzajamno osiguranje, kreditna unija, Organizator, Zagreb, 2010, p. 18

112 Articles 555 (1) and 556 of the Companies Act

113 For tax aspects of business transfers see an overview in CEPOR, op. cit., note 84, p. 17 
Croatian tax law recognizes that spouses, as well as children and parents are excluded from the inheritance and gift taxes. ${ }^{114}$ Also, the transfer of goods and property rights to one or more heirs in case of continuation of economic activity is not subject to value added taxation. ${ }^{115}$ Further, inheritance and gifts are not considered personal income for the purposes of establishing the personal income taxes. ${ }^{116}$ Thus, if the business is transferred among the family members as defined by the article 9 of the Local Taxes Act, the heirs are not obliged to pay any taxes at all. Such a solution is completely in line with the Commission's Recommendation 1994, and provide for a very favorable framework for transferring the family business among the family members.

On the other hand, the consequences are different if the business is transferred to third person, either as a gift or through a sale. The inheritance and gift tax is payable at the rate of $4 \% .{ }^{117}$ For the sale of the business, there is a difference if a seller is a natural person or it has a legal personality. If the seller is a natural person, the tax rate of $12 \%$ applies, plus surtax on income tax introduced by local governments. ${ }^{118}$ If the seller is a legal person, than the tax rates are $18 \%$ or $12 \%$ depending on the revenues of the legal person in the tax period. ${ }^{119}$ The potential buyers and sellers shall most certainly take into account these taxes when structuring the sale, especially when deciding on asset or share transactions for business transfers.

\section{WHAT SHOULD BE THE NEXT STEPS?}

It is clear that the EU took mostly the soft law approach when dealing with the challenges of family businesses. It seems that it was partly working well while there was some level of scrutiny over the Member States, especially in twelve years

114 Article 9 of the Local Taxes Act, Official Gazette, No. 115/2016, 101/2017. See also Friganović, M., Oporezivanje darovanja u Republici Hrvatskoj, Računovodstvo i porezi u praksi, no. 6, 2011, pp. 82-98, p. 84

115 Article 22 of the Regulation on value added tax, Official Gazette, No. 79/2013, 85/2013, 160/2013, 35/2014, 157/2014, 130/2015, 115/2016, 1/2017, 41/2017, 128/2017, 106/2018, 1/2019, 1/2020

116 Article 8 (2) of the Pesonal Income Tax Law, Official Gazette, No. 115/2016, 106/2018, 121/2019, $32 / 2020$

117 Article 8 of the Local Taxes Act. However, it is not clear whether all types of business shares fall within the scope of this provision. While the article 4 of the Local Taxes Act includes securities such as shares of the joint-stock companies, it remains silent on shares of all other company types, partnerships and crafts in Croatia. This leaves the space for interpretation that business shares which are not securities do not fall under the obligation to pay inheritance and gift taxes. See also Friganović, op. cit., note 114, p. 83

118 Article 67 and article 70 of the Pesonal Income Tax Law. Interestingly, the taxes on capital gains are introduced recently, at the beginning of 2016

119 Article 28 of the Corporate profit tax Act, Official Gazette, No. 177/04, 90/05, 57/06, 146/08, 80/10, $22 / 12,148 / 13,143 / 14,50 / 16,115 / 16,106 / 18,121 / 19,32 / 20$ 
following the Recommendations 1994 through four reports on the progress made by the Member States. These reports were conducive to Member States to continue with their efforts together with further recommendations and examples of good practices found in Member States. After that period to date we practically no longer have an overview of what is going on in the national legislations and practices of Member States. Thus, we can hardly evade the conclusion that the efforts made on the EU level regarding the family businesses came to a standstill. Thus, we believe that new comparative studies and recommendations should be introduced on the EU level primarily to maintain the communication between the Members States on this issue, and to steadily remind them to strive towards more active policy towards family businesses and their challenges.

In author's opinion, soft law approach remains the best for introducing additional instruments in corporate governance of the family businesses. Irrespective of the company type in which the family business is established, there are available instruments, such as family constitution, family council, family office and other which already produced good results in companies which introduced them. ${ }^{120}$ Their main purpose is to conciliate the roles which members simultaneously have in family and in the business, especially when more generations are present in the business. A further good example is transferring the shares to foundations as a neutral party which can carry on the business strategy of the founders, and in the same time financially support the family members of the founders. ${ }^{121}$ To the best knowledge of the author, these corporate governance instruments are not implemented in Croatian family businesses, and we wholeheartedly call for introduction of such practices, as is the case in the practice of comparative Member States.

The issue of awareness of the special needs of the family businesses and what could legal, economic and fiscal experts contribute to enhance the internal strengths of family business is a constant goal. The focus should be on education of entrepreneurs in the faculties, as well as through short courses and workshops. Taking good examples from comparative practice as guidance for Member States is not a perfect tool, but it can serve as an inspiration to both public and private initiatives in enhancing the national market for family businesses.

120 For an overview see Braut Filipović, M., Specifičnosti upravljanja u obiteljskim društvima, Zbornik Pravnog fakulteta u Zagrebu, vol. 67, no. 6, 2018., pp. 935-962

121 For the role of foundations in ensuring the continuity of businesses see for example Hepperle, T., Stiftungen als Instrumente zur Lösung von Schnittstellenkonflikten, Eine empirische Untersuchung, Josef EUL Verlag, Lohmar-Köln, 2011. See also Thomsen, S.; Rose, C., Foundation Ownership and Financial Performance: Do Companies Need Owners?, European Journal of Law nad Economics, vol. 18, 2004, pp. 343-364 


\section{CONCLUSION}

The importance of family businesses for the economy of Member States is recognized on the EU level. Their challenges, primarily regarding the business transfer, were a topic of a few EU documents, where the first and the most important is the Commission's Recommendations 1994. However, the recommendations were never fully implemented in the Member States. The last document dealing with the family business was the European Parliament's Resolution on family businesses in Europe from 2015 which called for further development of the policy on both the EU and national levels for supporting the family businesses. However, no further action was commenced and it seems that the efforts for supporting family businesses came to a standstill on the EU level. However, the challenges which family businesses experience did not disappear. When looking closer to Croatian economy, family businesses are seen as an important factor. However, there is only a sporadic and fragmented policy towards supporting the family businesses. Regardless, the Croatian company law provides a good framework for building a successful family business. There is no obstacle for introducing any soft law instrument such as family constitution, family council and other. Also, shareholders can easily ensure for the continuity of the business after the transfer. Fiscal policy for transfer of family businesses is also among the most favorable in the Member States. Still, the general awareness of the soft law instruments that can be introduced in order to enhance the internal relations and plans for business transfers is seriously lacking. This article, thus, aims to further share the awareness of the family businesses and to remind that there is still a lot of work to be done on both EU and national levels in order to adequately address and to create a level playing field for one of the most important market player in the EU - the family businesses.

\section{REFERENCES}

\section{BOOKS AND ARTICLES}

1. Alpeza, M.; Grubišić, N.; Mikrut, M., Business Transfer Barometar Hrvatska, Centar za politiku razvoja malih i srednjih poduzeća i poduzetništva (CEPOR), Zagreb, 2015

2. Barbić, J., Pravo drustava, Društva kapitala, Svezak II.: društvo s ograničenom odgovornošću, drustvo za uzajamno osiguranje, kreditna unija, Organizator, Zagreb, 2010

3. Barbić, J., Pravo društava, Društva osoba, Organizator, Zagreb, 2019

4. Botero, I. C. et al., Family business research in the European context, European Journal of International Management, vol. 9, no. 2, 2015, pp. 139-159

5. Braut Filipović, M., Obiteljski ustav - instrument za stvaranje obiteljske i poslovne strategije u obiteljskim društvima, in: Slakoper, Z.; Bukovac Puvača, M.; Mihelčíć, G. (eds.), Liber Amicorum Aldo Radolović, Sveučilište u Rijeci, Pravni fakultet, Rijeka, 2018., str. 529-550 
6. Braut Filipović, M., Specifičnosti upravljanja u obiteljskim društvima, Zbornik Pravnog fakulteta u Zagrebu, vol. 67, no. 6, 2018., pp. 935-962

7. Crnković Pozaić, S., Overview of Family Business Relevant Issues, Country Fiche - Croatia, CEPOR, 2008

8. Duh, M., Family Businesses: The Extensiveness of Succession Problems and Possible solutions, in: Burger-Helmchen, T. (ed.), Entrepreneurship - Gender, Geographies and Social Context, IntechOpen, 2012, pp. 209-234

9. Fayolle, A.; Kyrö, P.; Ulijn, J.M. (eds.), Entrepreneurship Research in Europe: Outcomes and Perspectives, Edward Elgar Publishing, Cheltenham, 2005

10. Friganović, M., Oporezivanje darovanja u Republici Hrvatskoj, Računovodstvo i porezi u praksi, no. 6, 2011, pp. 82-98

11. Groth, T. et al., Familienunternehmen, Erfolgsstrategien zur Unternehmenssicherung, Deutscher Fachverlag, Frankfurt am Main, 2012

12. Hepperle, T., Stiftungen als Instrumente zur Lösung von Schnittstellenkonflikten, Eine empirische Untersuchung, Josef EUL Verlag, Lohmar-Köln, 2011

13. Jurić, D., Pravo društava, Pravni fakultet Sveučilišta u Rijeci, Rijeka, 2020

14. Koeberle-Schmid, A.; Kenyon-Rouvinez, D.; Poza, E. J., Governance in Family Enterprises, Maximizing Economic and Emotional Success, Palgrave Macmillan, New York, 2014

15. Kormann, H., Governance des Familienunternehmens, Springer, eBooks, Wiesbaden, 2017

16. Mezulić Juric, P.; Alpeza, M., Izazovi prijenosa poslovanja u malim i srednjim poduzećima, CEPOR, Zagreb, 2017

17. Renko, N.; Kuvačić, D.; Renko, S., Analiza empirijskog istraživanja o obiteljskom poduzetništvи u Republici Hrvatskoj, Ekonomski pregled, vol. 58. no. 1-2, 2007, pp. 72-90

18. Senčur Peček, D.; Laleta, S., Ugovor o radu i ugovor o djelu: područje primjene radnoga zakonodavstva, Zbornik Pravnog fakulteta Sveučilišta u Rijeci, 2018, vol. 39. no. 1, pp. 411-456

19. Senegović, I.; Bublić, V.; Ćorić, G., Family Business Succession Risks: the Croatian Context, in: Dana, L-P.; Ramadani, V. (eds.), Family Businesses in Transition Economies, Management, succession and Internationalization, Springer, 2015, pp. 175-199

20. Thomsen, S.; Rose, C., Foundation Ownership and Financial Performance: Do Companies Need Owners?, European Journal of Law nad Economics, vol. 18, 2004, pp. 343-364

21. Vukić, B., Osnivači, nasljednici, menadžeri, Beletra, Zagreb, 2019

22. Zahra, S.A.; Wright, M., Entrepreneurship’s Next Act, Academy of Management Perspectives, vol. 25, no. 4, 2011, pp. 67-83

\section{EU LAW}

1. 94/1069/EC: Commission Recommendation of 7 December 1994 on the transfer of small and medium-sized enterprises, Official Journal L 385, p. 14-17

2. Communication from the Commission on the transfer of small and medium-sized enterprises, OJ C 93, 28.3.1998, p. 2-12

3. Communication from the Commission to the Council, the European Parliament, the European Economic and Social Committee and the Committee of the Regions, Implementing 
the Lisbon Community Programme for Growth and Jobs, Transfer of Businesses - Continuity through a new beginning, COM (2006) 177 final, Brussels, 2006

4. Communication from the Commission to the Council, the European Parliament, the European Economic and Social Committee and the Committee of the Regions - "Think Small First" - A “Small Business Act” for Europe, COM/2008/0394 final

5. Communication from the Commission to the European Parliament, The Council, The European Economic and Social Committee and the Committee of the Regions, Entrepreneurship 2020 Action Plan Reigniting the entrepreneurial spirit in Europe, COM/2012/0795 final

6. Directive 2011/7/EU of the European Parliament and of the Council of 16 February 2011 on combating late payment in commercial transactions, OJ L 48, 23.2.2011

7. European Commission, Fostering Transparent Marketplaces for the Transfer of Businesses in Europe, Report of the Expert Group, 2006

8. European Parliament resolution of 10 March 2009 on the Small Business Act, OJ C 87E, 1.4.2010

9. European Parliament resolution of 5 February 2013 on improving access to finance for SMEs, OJ C 24, 22.1.2016

10. European Parliament resolution of 8 September 2015 on family businesses in Europe 2014/2210(INI)

11. Opinion of the European Economic and Social Committee on 'Promoting SMEs in Europe with a special focus on a horizontal legislative SME approach and respect of the SBA's "think small first"' (exploratory opinion), OJ C 197, 8.6.2018

12. Proposal for a Council Directive amending Directive 2006/112/EC on the common system of value added tax as regards the special scheme for small enterprises, COM/2018/021 final

13. Proposal for a Council Regulation on the statute for a European private company, COM/2008/0396 final

14. Written question No. 2016/96 by Concepció FERRER to the Commission. Transfer of small and medium-sized enterprises, OJ C 385, 19.12.1996

15. Written Question No. 235/96 by Concepció FERRER to the Commission, Transfer of enterprises, OJ C 137, 8.5.1996.

\section{LIST OF NATIONAL REGULATIONS}

1. Companies Act, Official Gazette, No. 111/93, 34/99, 121/99, 52/00, 118/03, 107/07, $146 / 08,137 / 09,125 / 11,152 / 11,111 / 12,68 / 13,110 / 15,40 / 19$

2. Corporate profit tax Act, Official Gazette, No. 177/04, 90/05, 57/06, 146/08, 80/10, 22/12, $148 / 13,143 / 14,50 / 16,115 / 16,106 / 18,121 / 19,32 / 20$

3. Crafts Act, Official Gazette, No. 143/13, 127/19

4. Family Farms Act, Official Gazette, Nos. 29/18, 32/19

5. Local Taxes Act, Official Gazette, No. 115/2016, 101/2017

6. Obligations Act, Official Gazette, No. 35/05, 41/08, 125/11, 78/15, 29/18

7. Pesonal Income Tax Law, Official Gazette, No. 115/2016, 106/2018, 121/2019, 32/2020 
8. Regulation on value added tax, Official Gazette, No. 79/2013, 85/2013, 160/2013, 35/2014, 157/2014, 130/2015, 115/2016, 1/2017, 41/2017, 128/2017, 106/2018, 1/2019, 1/2020

\section{WEBSITE REFERENCES}

1. CEPOR, [https://www.cepor.hr/], accessed 02. April 2020

2. CEPOR, Minivodic za poduzetnike, Prijenos poslovanja, 2019, [https://www.mingo.hr/public/Minivodic_CEPOR_web\%202019.pdf], accessed 04. April 2020

3. CEPOR, Razvoj i održivost obiteljskih poduzeća u Hrvatskoj, 2012 [http://www.cepor.hr/ news/obiteljska-poduzeca/FB_policy\%20brief_CEPOR.pdf], accessed 06. April 2020

4. CEPRA, [http://www.cepor.hr/cepra], accessed 02. April 2020

5. Cikać, V., Pravni aspekti nasljecivanja obiteljskih poduzeća u Hrvatskoj, CEPOR, 2012, [http://www.cepor.hr/news/obiteljska-poduzeca/CEPOR_policy\%20osvrt_Pravni\%20aspekti\%20nasljedjivanja\%20obiteljskih\%20poduzeca\%20u\%20Hrvatskoj.pdf], accessed 08. April 2020

6. COSME, [https://ec.europa.eu/growth/smes/cosme_hr], accessed 10. April 2020

7. Croatian Bureau of Statistics, Number and structure of business entities, September 2019, [https://www.dzs.hr/], accessed 13. April 2020

8. European Commission, Final report of the Expert Group on the Transfer of Small and Medium-sized Enterprises, May 2002, [https://ec.europa.eu/docsroom/documents/2158/attachments/1/translations/en/renditions/native], accessed 22. March 2020

9. European Commission, Final report of the expert Group, Overview of Family-Business-Relevant Issues: Research, networks, policy measures and existing studies, November 2009, [https:// ec.europa.eu/docsroom/documents/10388/attachments/1/translations/en/renditions/native], accessed 06. April 2020

10. European Commission, Final report of the MAP 2002 project, August 2003, [https://www. cbs.dk/files/cbs.dk/best_report-08-2003_3667.pdf], accessed 26. March 2020

11. European Commission, Report of the Expert Group, Thinks Small First - Considering SME interests in policy-making including the application of an „SME Test“, March 2009, [https:// ec.europa.eu/docsroom/documents/2664/attachments/1/translations/en/renditions/native], accessed 26. March 2020

12. European Family Businesses (EFB), [http://www.europeanfamilybusinesses.eu/], accessed 19. February 2020

13. European Family Businesses (EFB), Family Business Succession and Transfers: Challenges and Opportunities, 2016, [https://ec.europa.eu/transparency/regexpert/?do=groupDetail.groupMeetingDoc\&docid=29616], accessed 20. February 2020

14. European Investment Bank, [https://www.eib.org/en/projects/regions/european-union/croatia/index.htm], accessed 10. April 2020

15. Jamstveni program PLUS, [https://hamagbicro.hr/financijski-instrumenti/kako-do-jamst$\mathrm{va} / \mathrm{msp} /$ nacionalna-jamstva/plus/], accessed 04. April 2020

16. KPMG\&EFB: European family business barometer, 2019, [http://www.europeanfamilybusinesses.eu/uploads/Modules/Publications/gm-tl-01172-european-family-barometer-2019_ v11_web.pdf], accessed 06. April 2020 
17. LIDER - business journal, [https://lider.events/obiteljske/arhiva/], accessed 04. April 2020

18. Ministarstvo poduzetništva i obrta, Akcijski plan za provedbu Strategije razvoja poduzetništva žena u Republici Hrvatskoj 2014.-2020., [https://www.mingo.hr/public/Poduzetnistvo/Akcijski_plan_provedbe_Strategije_razvoja_poduzetnistva_zena_RH12117.pdf], accessed 09. April 2020

19. Ministarstvo poduzetništva i obrta, Strategija razvoja poduzetništva u Republici Hrvatskoj 2013.-2020., [http://www.europski-fondovi.eu/sites/default/files/dokumenti/Strategy-HR-Final.pdf], accessed 09. April 2020

20. Ministry of the Economy, Entrepreneurship and Crafts, [https://www.mingo.hr/], accessed 04. April 2020

21. Nachfolgebörse, [www.nachfolgeboerse.at], accessed 22. March 2020

22. Nexxt-Change Unternehmensbörse, [www.nexxt-change.org], accessed 22. March 2020

23. Obiteljsko poduzetništvo, Faculty of Economics in Osijek, [http://www.efos.unios.hr/ obiteljsko-poduzetnistvo/opis-kolegija/], accessed 09. April 2020

24. Postgraduate specialist study programme in Corporate Finance Law at the University of Rijeka, Faculty of Law, [https://pravri.uniri.hr/en/study-programmes/corporate-finance-law. html], accessed 09. April 2020

25. Radionice za obiteljska poduzeća, CEPOR, [https://www.cepor.hr/edukacije/radionice-za-obiteljska-poduzeca/], accessed 03. April 2020

26. Trgovačka društva i obrti, [https://www.hok.hr/gospodarstvo-i-savjetovanje/statistika/trgovacka-drustva-i-obrti], accessed 10. April 2020 